\title{
Strategies for the creation of tourism routes aimed at the development of local communities: a study in Brazil
}

\author{
S. F. Queiroz \\ Pontifícia Universidade Católica de Minas Gerais, Brazil
}

\begin{abstract}
Similarly to other existing historic ways, the route shown in this study originates from footpaths made by native Indians, at the time of their walking across the still virgin Brazilian lands. However, it was in the beginning of the 17 th century that the construction of what is known today as the Estrada Real occurred. The Estrada Real was formed by royal ways, that is to say, ways belonging to the Portuguese Crown, built exclusively under its consent, to permit access to the gold and diamond reserves of the state of Minas Gerais in Brazil. Through those ways, the precious minerals reached the ports in the cities of Paraty and Rio de Janeiro, from where they were shipped to the Kingdom of Portugal. At that time, this route became the main method of communication and transportation of goods across the Brazilian lands, bringing growth to that region. Nowadays, the revival of ancient routes aimed at tourism purposes belongs to a group of modalities, which become more and more outstanding in the market of this sector. In this context, and by means of governmental initiative, the Estrada Real has been reactivated as part of a tourism itinerary that portrays the colonial Brazil of the past. This study has been carried out to discuss the importance of the development of routes that promote the creation of tourism nets, as well as learning about the perceptions of the communities of three important municipalities that form the Estrada Real, Diamantina, Serro and Conceição do Mato Dentro, with regard to this route. The research has been conducted through group interviews with representatives of those communities and shows their involvement and participation in this process.
\end{abstract}

Keywords: tourism routes, Estrada Real, tourism development, involvement of the local community. 


\section{Introduction}

The first way opened by the Portuguese Crown, leading to the gold and diamond reserves in Brazil, is known as the Old Road. The initiative came up in 1674, when by request of the king of Portugal, the bandeirante Fernão Dias, an expedition member, set off an incursion throughout the interior of Brazil, in order to reach a gold and diamond region named Sabarabuçu. Fernão Dias' expedition moved across the place corresponding to the present state of Minas Gerais, founding the first villages. The Old Road was, for a while, the main route for access and supply of the regions in Minas Gerais, connecting the villages of São Paulo to the ports of Parati and Rio de Janeiro [1].

However, this way led to a long deviation. So, by means of an official project of the Portuguese Crown, aiming at shortening this route, the bandeirante Borba Gato, along with Artur de Sá e Menezes, governor of the captaincy of Rio de Janeiro, commanded an expedition that brought about the creation of the New Road.

In the first decades of the 18th century, the roads were opened for pedestrians, and soon after that, they were improved for the traffic of working animals. From then on, the New Road became the main access from Rio de Janeiro to the mining region, making the Old Road into a secondary route.

Some years later, the New Road became extremely populated, with several ranches, plantations and villages. The consolidation of this way transformed the economic and political context of colonial Brazil. This way permitted the city of Rio de Janeiro to centralize the route for supply and circulation of the mining region and its port was used to ship the gold [2].

\section{The tourism project Estrada Real}

With the ending of the economic cycle of the mining region, and the growth of the industrial process in Brazil, the royal ways were forgotten for a long time, permitting, on the other hand, their conservation.

In the last decade of the past century, the route was reactivated, by an initiative of Minas Gerais Industrial Federation (FIEMG). In this period, the Estrada Real Institute, a non-profit organization, was created with the purpose to bring back the historic cultural heritage of the royal ways, as well as to promote the social growth of the region by means of the tourism activity.

Since its inauguration, the institute has made efforts to coordinate actions along the Estrada Real, aiming at the consolidation of the way as a tourism product. In this sense, the Decree 41205/00 regulated the Law 13173/79 of the government of Minas Gerais state, which established the Incentive Program for the Development of the Estrada Real Tourism Potential. This law regulates the actions of the government, as well as the non-governmental private entities which work for the tourism development in the region along the way [3].

Nowadays, the tourism route Estrada Real is formed by 177 municipalities, extending across three Brazilian states: Minas Gerais (162 municipalities), Rio de Janeiro (8 municipalities) and São Paulo (7 municipalities). 
The journey performed by the first expeditions in the country, motivated by the gold rush, originated the Old Road, which today starts in São Paulo, cutting across Cunha, Guaratinguetá, Mantiqueira Mountains, Passa-Quatro, Itanhandu, Pouso Alto, Baependi, Cruzilia, Ibituruna, São João Del Rei, Mariana and Ouro Preto, fig. 1 [4].

The New Road, second variant of the Estrada Real, which comprised a shorter route for communication and transportation of goods from Rio de Janeiro to the mining region, nowadays runs through Petrópolis, Juiz de Fora, Barbacena, Ouro Branco, Mariana and Ouro Preto. The discovery of diamonds in those lands caused the way to be extended up to Diamantina, fig. 1 [4].

Along the route, there are natural parks, thermal cities and places included in the World Heritage List by UNESCO, as they preserve the baroque architecture of the colonial period. As regards to the natural surroundings, the way traverses zones of varied climate and vegetation, showing the diversity of the landscapes existing in the country.

These initiatives rebuild the history, contributing with the divulgation and promotion of the old ways, reviving historic values of the colonial past of Brazil [2]. It is believed that the future of these ways is concentrated on a group of projects and actions, which depend on the government entities, the private companies and the non-governmental organizations. It is also necessary that the local community mobilizes in order to preserve the existing natural and cultural heritage, so that these royal ways become a worldwide reference, allowing the sustainable development of the societies involved.

Besides, it is important for the tourism sector to be more and more aware of activities like this, which promote an effective participation of the tourist. Efforts must be made for the tourist to have a more productive contact with the local habits and culture. A deeper interaction with the environment alerts us for its importance and preservation, permitting a better enjoyment of all the beauty present in those ways.

\section{Cities involved in the study}

\subsection{Conceição do Mato Dentro}

The region where the city of Conceição do Mato Dentro is located was populated in the first years of the 18th century, when the bandeirantes, who found gold in the place, erected the chapel of Nossa Senhora da Conceição do Mato Dentro [5].

At first, the district of Conceição do Mato Dentro arose from the auriferous activities. However, written documents from the middle of this same century, report that the district took advantage of its location to guarantee its economic and commercial stability.

The city of Conceição do Mato Dentro is located in the Espinhaço Mountains, in the central portion of the state of Minas Gerais. Its population is of approximately 18,500 inhabitants, scattered in a territory of 1,671 square kilometres [6]. 


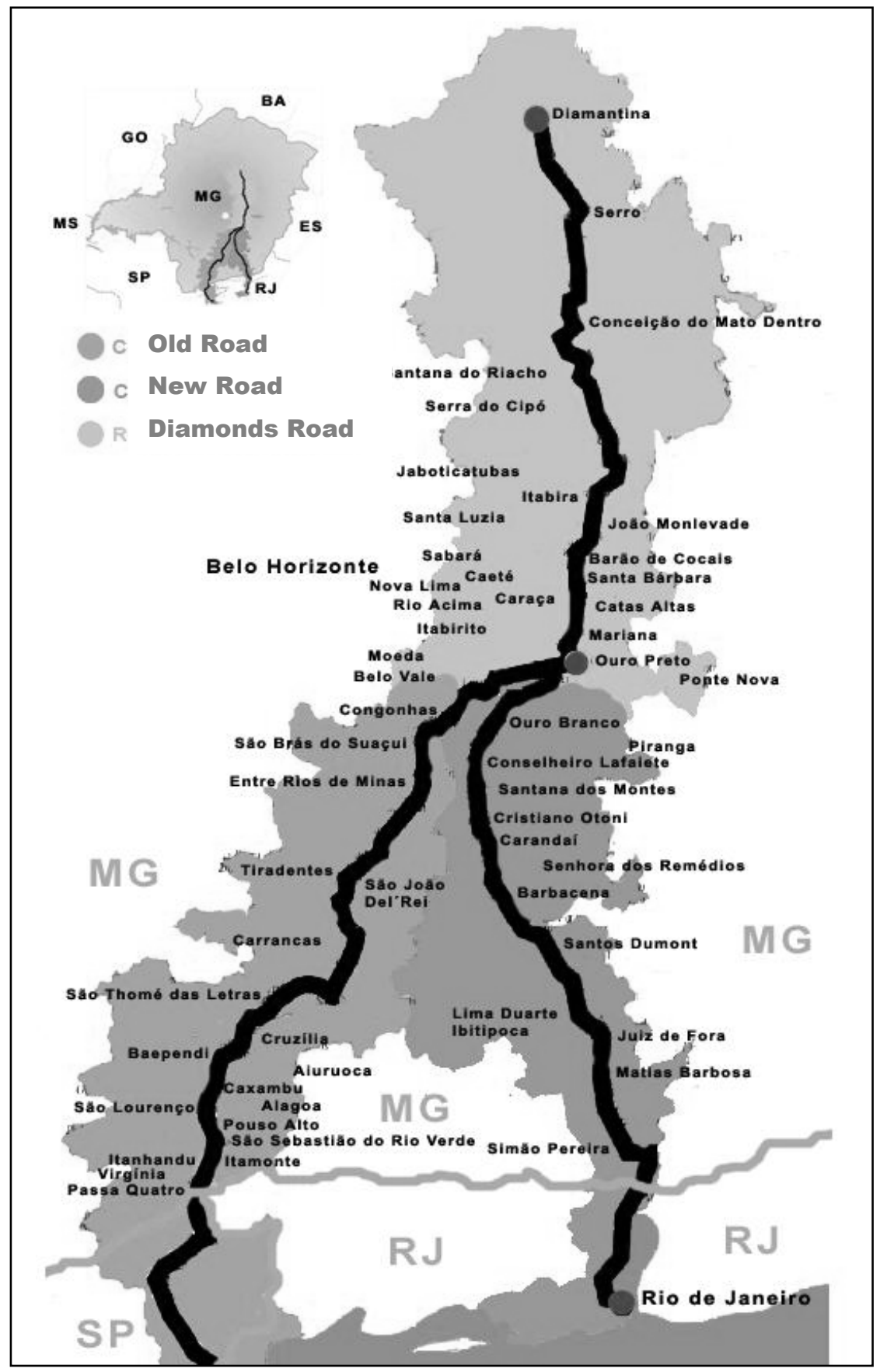

Figure 1: $\quad$ Estrada Real map. 
Several manifestations of the culture of Conceição do Mato Dentro have been preserved since the colonial period. Among them, the religious celebrations of Rosário and São Sebastião are outstanding. The most famous celebration of the city is the Bom Jesus do Matozinhos Jubilee, which always takes place in June.

As all historic cities, Conceição do Mato Dentro features a varied architectonic collection, in spite of the modernization process suffered by a great deal of its buildings.

Besides the historic and cultural heritage, there is also an outstanding natural heritage. The city has a large protected environmental area, where the third largest waterfall of the country, named Cachoeira do Tabuleiro, is located.

\subsection{Serro}

The first settlements of the Serro Frio region began to develop along the banks of Jequitinhonha River and its tributaries around 1714. In 1720, in an effort to organize the juridical system of the region, the Judicature of Serro Frio was created, with headquarters in Vila do Príncipe. On March 06th, 1838, the village became a city, being named Serro [1].

Due to its architectural and urbanistic complexes and its historical importance for the Brazilian colonization, Serro was the first municipality registered as Cultural Heritage by the National Heritage Council, in April 1938. Besides, the cheese produced in Serro, an agro industrial product and cultural heritage dating back three centuries, was awarded in 2002 the title of first Intangible Heritage of the state of Minas Gerais.

The population of Serro today is estimated in 22,000 inhabitants, scattered throughout the urban and rural areas of the municipality, which comprise a territory of 1,218 square kilometres.

Since the 18th century, the celebrations held in Vila do Príncipe were frequent and featured religious ceremonies and dances. At present, the most popular celebrations of Serro are Divino and Rosário, which take place in July and May respectively. During this period, the religious roots and the folklore are manifested.

\subsection{Diamantina}

The Arraial do Tijuco was born around 1720, period when the Portuguese Crown decided to install Senates and Council Houses in the villages existing in Brazil, aiming at centralizing its administrations, as well as inspecting them in a more effective way. In a short time, the village became one of the most important economic centres of colonial Brazil.

Besides gold, the region was also famous for the diamond extraction. In a short time, a large contingent of immigrants, mostly Negro slaves and Portuguese, was formed. A disarticulated colonization process started along the banks of Grande River, generating unhealthy living conditions, as a consequence of inadequate sanitation, hygiene and alimentation [1].

In spite of the rigid moral rules imposed by both the Portuguese government and the Catholic Church, the daily life in Arraial do Tijuco suffered cultural, 
economic and political changes, thus creating a new ethnical and cultural identity manifested in culinary traditions, dance and religious rituals [1].

From the 18th century on, the extraction of gold and diamond began to fade, due to the exploiting conditions imposed by the Portuguese government, mainly after the beginning of the revolutionary movements, which occurred in Minas Gerais, causing rebellions and intensifying the liberation process in the country.

In 1831, Arraial do Tijuco was transformed into a city, being named Diamantina. Diamantina developed through the textile industry, metal melting workshops. The construction of the railway Estrada de Ferro Central do Brasil also contributed significantly for the growth of the city.

Due to the great edifications and gold-adorned churches, in 1938, the architectural complex of the historical centre of the city was registered by the National Heritage Council. In the late 90's, Diamantina was included in the World Heritage List by UNESCO.

The population of Diamantina is around 44,000 inhabitants today, scattered throughout a territory of 3,870 square kilometres. Nowadays, its activities are mainly related to tourism, commerce, cattle breeding and handicraft.

Among some of the attractions, two are outstanding. The former is Chica da Silva's house, National Heritage Council (IPHAN) headquarters at present. Chica da Silva was a Negro slave who lived in Arraial do Tijuco during the second half of the 18th century. She became notorious for receiving her emancipation and for gaining social recognition, after getting married to a rich and powerful worker of the Portuguese Crown, challenging the society at that time.

The latter is Juscelino Kubitschek's house. Juscelino Kubitschek was born in Diamantina and was the president of Brazil from 1956 to 1960, a period which brought an important modernization process to the country. He was responsible for the planning and the construction of the Brazilian capital, the city of Brasília.

Among the several baroque churches of the city, we can mention Nossa Senhora do Carmo, Bonfim, Mercês and São Francisco.

\section{Main results of the interviews with the local community representatives of the cities analysed}

The study aimed at learning the perceptions which the local communities of the three cities involved have towards the tourism development generated by the Estrada Real. The main benefits, the perceived costs, the level of implication with the development of the tourism activity, the level of receptiveness to the tourist, among other aspects were collected.

The process of group interview was the method chosen for this analysis, as it allows the collection of a wider range of questions and opinions, and also, enables the collection of more significant information. This way, the goal was to reach interaction through a dialogue searching for the understanding of what the local community believes and wishes, as regards to the variables involving the Estrada Real. 
Between fifteen and twenty representatives of each city were invited to take part on the discussion, summing up 52 participants. The sampling system made sure that each group could be made up with people from both sexes, different age ranges, education and occupation.

Tables 1-4 present and discuss the main information collected in the three cities.

\section{Conclusion}

The data collected by means of group interviews bring up the following questions:

1st The cities analysed originated from the same mineral extraction process of colonial Brazil, therefore they present a very similar history.

2nd The end of the extraction period happened, in each of these cities, at different periods and for different reasons.

3rd Consequently, the cities have traced distinct growth paths, causing a heterogeneous system of basic infrastructure.

4th Nowadays, there is little uniformity related to tourism development in these cities, and great expectancy towards the formation of a tourism network promoted by the Estrada Real.

5th The participation and the involvement of the local population in the planning of the activities are scarce.

Table 1: Definitions about the Estrada Real according to the interviewees.

\begin{tabular}{|c|c|c|}
\hline Conceição do Mato Dentro & Serro & Diamantina \\
\hline $\begin{array}{l}\text { 'The Estrada Real was 'the } \\
\text { gold path, through which } \\
\text { they took away our riches'. }\end{array}$ & $\begin{array}{l}\text { 'The way on which the } \\
\text { riches of the city were } \\
\text { taken to the port of Paraty } \\
\text { and to Portugal.' }\end{array}$ & $\begin{array}{l}\text { The Estrada Real was 'the } \\
\text { path where gold and } \\
\text { diamond } \\
\text { transported.' }\end{array}$ \\
\hline $\begin{array}{l}\text { Nowadays, the Estrada } \\
\text { Real represents 'the revival } \\
\text { of the history and the } \\
\text { culture of the cities.' } \\
\text { 'A tourism segment that } \\
\text { has come up to bring } \\
\text { investments from the } \\
\text { government to the cities, } \\
\text { generating development } \\
\text { and sustainability.' } \\
\text { 'A new tourism route of } \\
\text { Minas Gerais, built to } \\
\text { explore tourism in the } \\
\text { state.' }\end{array}$ & $\begin{array}{l}\text { The Estrada Real is 'the } \\
\text { reconstitution of the road } \\
\text { of the gold way'. } \\
\text { 'A government program } \\
\text { to generate improvement, } \\
\text { jobs, housing, and } \\
\text { education and to bring } \\
\text { development to the } \\
\text { region, by means of } \\
\text { tourism.' }\end{array}$ & $\begin{array}{l}\text { The Estrada Real is 'a } \\
\text { brand, it is the creation of } \\
\text { products to motivate } \\
\text { tourism, through the } \\
\text { valuation of the history } \\
\text { and the economic } \\
\text { development.' } \\
\text { 'It is a new milestone for } \\
\text { tourism development in } \\
\text { Diamantina.' } \\
\text { 'Today, it is a place with } \\
\text { receptive people and } \\
\text { beautiful churches.' }\end{array}$ \\
\hline
\end{tabular}


Table 2: Perceptions about the Estrada Real development according to the interviewees.

\begin{tabular}{|c|c|c|}
\hline $\begin{array}{c}\text { Conceição do Mato } \\
\text { Dentro }\end{array}$ & Serro & Diamantina \\
\hline $\begin{array}{l}\text { The Estrada Real has } \\
\text { contributed for the } \\
\text { development of local } \\
\text { tourism, by means of the } \\
\text { valuation of the city, the } \\
\text { culture, the natural and } \\
\text { gastronomic attractions. }\end{array}$ & $\begin{array}{l}\text { The Estrada Real program } \\
\text { has not brought tourism } \\
\text { development for the city } \\
\text { yet, as the government has } \\
\text { not made significant local } \\
\text { investments. }\end{array}$ & $\begin{array}{l}\text { The Estrada Real program } \\
\text { has not contributed for the } \\
\text { local development yet, as } \\
\text { although it has been } \\
\text { divulgated, great } \\
\text { investments in the local } \\
\text { infrastructure are not } \\
\text { perceived yet. }\end{array}$ \\
\hline $\begin{array}{l}\text { The initiative has } \\
\text { promoted a larger } \\
\text { divulgation of the city, an } \\
\text { increase in the public and } \\
\text { private investments and in } \\
\text { the flow of tourists. }\end{array}$ & $\begin{array}{l}\text { The Estrada Real has } \\
\text { promoted a slight increase } \\
\text { in the divulgation of the } \\
\text { city, generated by the } \\
\text { realization of horseback } \\
\text { riding and expeditions. }\end{array}$ & $\begin{array}{l}\text { The interviewees believe } \\
\text { that the Estrada Real will } \\
\text { still promote the } \\
\text { development of the local } \\
\text { economy, the roads and } \\
\text { the infrastructure as a } \\
\text { whole. }\end{array}$ \\
\hline $\begin{array}{l}\text { The Estrada Real should } \\
\text { promote the local } \\
\text { ecotourism better. }\end{array}$ & $\begin{array}{l}\text { There is considerable } \\
\text { expectancy that the project } \\
\text { is directly related to the } \\
\text { development of the asphalt } \\
\text { connecting the cities } \\
\text { comprised by this route. }\end{array}$ & $\begin{array}{l}\text { The Estrada Real should } \\
\text { promote the local } \\
\text { ecotourism better. }\end{array}$ \\
\hline $\begin{array}{l}\text { The development of the } \\
\text { Estrada Real is related to a } \\
\text { strong dependency on the } \\
\text { public institutions. }\end{array}$ & $\begin{array}{l}\text { The Estrada Real can } \\
\text { generate an improvement } \\
\text { of the quality of the local } \\
\text { labour force, as well as the } \\
\text { revival of the citizens' } \\
\text { pride to belong to a city of } \\
\text { great historical } \\
\text { importance. }\end{array}$ & $\begin{array}{l}\text { The Estrada Real will } \\
\text { increase the number of } \\
\text { tourists who visit the city. }\end{array}$ \\
\hline
\end{tabular}

From the questions above, it is possible to conclude that the consolidation of the routes and tourism circuits depends on actions which can promote the recognition of a concrete and unique identity for the destinations involved. The establishment of this identity depends on a work based on the potentialities that the destinations have in common.

The cities analysed share an important colonial past. The existing potentialities, such as the artistic and cultural heritage from the baroque period, should constitute the basis of the construction of an identity capable of connecting these destinations, as the essential significance of the Estrada Real lies on this aspect. 
Table 3: Perceptions about local tourism development according to the interviewees.

\begin{tabular}{|c|c|c|}
\hline $\begin{array}{c}\text { Conceição do Mato } \\
\text { Dentro }\end{array}$ & Serro & Diamantina \\
\hline $\begin{array}{l}\text { The tourism sector is } \\
\text { essential for the city, as it } \\
\text { generates jobs, income and } \\
\text { economic development for } \\
\text { the region as a whole. }\end{array}$ & $\begin{array}{l}\text { There aren't either private } \\
\text { or public policies in the } \\
\text { cities prioritizing actions } \\
\text { of tourism development. }\end{array}$ & $\begin{array}{l}\text { There is a lack of } \\
\text { partnerships between the } \\
\text { public and the private } \\
\text { sectors to promote tourism } \\
\text { development of the city. }\end{array}$ \\
\hline $\begin{array}{l}\text { The existing relation } \\
\text { between the population } \\
\text { and the tourists shows, } \\
\text { most of the times, } \\
\text { congeniality, acceptance } \\
\text { and hospitality. }\end{array}$ & $\begin{array}{l}\text { The community is } \\
\text { unaware of the history of } \\
\text { the values of the city and } \\
\text { therefore they cannot } \\
\text { provide information for } \\
\text { the tourists. }\end{array}$ & $\begin{array}{l}\text { Nowadays, the tourists are } \\
\text { the main income source of } \\
\text { the city. }\end{array}$ \\
\hline $\begin{array}{l}\text { The tourism activity is not } \\
\text { sufficient to supply the } \\
\text { deficiencies of the social } \\
\text { and economic system of } \\
\text { the cities in the region. }\end{array}$ & $\begin{array}{l}\text { The city is visited by few } \\
\text { tourists and its potential is } \\
\text { under explored. }\end{array}$ & $\begin{array}{l}\text { The city has not planned } \\
\text { its tourism actions } \\
\text { properly. }\end{array}$ \\
\hline $\begin{array}{l}\text { Tourism is partially } \\
\text { related to the increase of } \\
\text { the criminality, as the } \\
\text { sector contributes for the } \\
\text { divulgation and the } \\
\text { attraction of all kinds of } \\
\text { public to the city. }\end{array}$ & $\begin{array}{l}\text { Tourism is not directly } \\
\text { related to the increase of } \\
\text { the inflation and the local } \\
\text { speculation. }\end{array}$ & $\begin{array}{l}\text { The increase of criminality } \\
\text { in the past years is not } \\
\text { related to tourism; instead, } \\
\text { it is a consequence of the } \\
\text { social and economic } \\
\text { disarticulation caused by } \\
\text { the end of the mineral } \\
\text { extraction in the region. }\end{array}$ \\
\hline $\begin{array}{l}\text { The community relishes } \\
\text { the cultural activities } \\
\text { which are offered to the } \\
\text { tourists, thus enriching the } \\
\text { routine of the city. }\end{array}$ & $\begin{array}{l}\text { There is little participation } \\
\text { of the population in local } \\
\text { tourism events. }\end{array}$ & $\begin{array}{l}\text { The local community does } \\
\text { not have access to tourism } \\
\text { activities. They feel } \\
\text { excluded and unaware of } \\
\text { the attractions offered. }\end{array}$ \\
\hline $\begin{array}{l}\text { The benefits of tourism } \\
\text { only reach a small part of } \\
\text { the population. }\end{array}$ & $\begin{array}{l}\text { The interviewees perceived } \\
\text { an increase in the number } \\
\text { of jobs in inns, restaurants, } \\
\text { stores of typical products } \\
\text { (handicraft, } \\
\text { cheese). }\end{array}$ & $\begin{array}{l}\text { The population does not } \\
\text { benefit directly from the } \\
\text { local tourism investments. }\end{array}$ \\
\hline $\begin{array}{l}\text { The tourism infrastructure } \\
\text { of the city is not sufficient } \\
\text { to meet the current } \\
\text { demand from the tourists. }\end{array}$ & $\begin{array}{l}\text { The infrastructure offered } \\
\text { by the city is not ideal to } \\
\text { meet the tourists' demand. }\end{array}$ & $\begin{array}{l}\text { The tourism infrastructure } \\
\text { of the city is not sufficient } \\
\text { to meet the current } \\
\text { demand from the tourists. }\end{array}$ \\
\hline
\end{tabular}


Table 4: Perceptions about the participation of the community in the processes of tourism development according to the interviewees.

\begin{tabular}{|c|c|c|}
\hline $\begin{array}{c}\text { Conceição do Mato } \\
\text { Dentro }\end{array}$ & Serro & Diamantina \\
\hline $\begin{array}{l}\text { The community has little } \\
\text { participation on the } \\
\text { discussions related to } \\
\text { tourism development of } \\
\text { the city. }\end{array}$ & $\begin{array}{l}50 \% \text { of the interviewees } \\
\text { answered that they had } \\
\text { never taken part on a } \\
\text { discussion about tourism } \\
\text { development of the city. }\end{array}$ & $\begin{array}{l}\text { Most interviewees reported } \\
\text { they have not taken part on } \\
\text { meetings to discuss tourism } \\
\text { development of the city. }\end{array}$ \\
\hline $\begin{array}{l}\text { The local community is } \\
\text { unaware and does not } \\
\text { value the Tourism } \\
\text { Councils existing in the } \\
\text { city. }\end{array}$ & $\begin{array}{l}\text { The local community and } \\
\text { the businessmen of the } \\
\text { sector are not interested in } \\
\text { debating issues concerning } \\
\text { tourism development. }\end{array}$ & $\begin{array}{l}\text { The local community is } \\
\text { unaware and does not } \\
\text { value the Tourism } \\
\text { Councils existing in the } \\
\text { city. }\end{array}$ \\
\hline $\begin{array}{l}\text { The interviewees think it } \\
\text { is necessary to express } \\
\text { their opinions and they } \\
\text { believe that the } \\
\text { participation of everybody } \\
\text { is important for tourism } \\
\text { growth. }\end{array}$ & $\begin{array}{l}\text { The interviewees believe } \\
\text { that they should have more } \\
\text { influence on the decisions } \\
\text { about tourism. }\end{array}$ & $\begin{array}{l}\text { The local community does } \\
\text { not have the power to } \\
\text { make decisions about } \\
\text { tourism development of } \\
\text { the city. }\end{array}$ \\
\hline
\end{tabular}

On the other hand, the main difficulty for the management of a tourism network is related to the different kinds of demand and necessities of infrastructure present in the cities which form this network, generating complexity for the elaboration of a unified offer adaptable to these distinct realities [7].

It can be concluded that the main deficiencies detected in the development of routes like the Estrada Real come from management systems that do not observe the peculiarities of each tourism destination involved. Such conditions hinder the effectiveness of these activities, therefore making them unable to contribute to a process of collective growth of these destinations.

Finally, it is necessary to mention that tourism is not justified without meeting the expectancies and wishes of the local community and without an improvement of the life quality of the inhabitants of those places, who depend on their resources.

In this sense, the planning of a tourism activity cannot be an exclusive task of the public sector and the private organizations. The local community must be aware of its responsibilities. Actions concerning the future of the destinations must be decided by the main actors involved.

It is believed that the participation of the involved communities is an essential point for the discussions about the Estrada Real to reach a regional ambit and for the cities to have a lead role in this process [7]. This effort can ensure joint 
management actions which promote the necessary synergy for the accomplishment and the competitiveness of the activity in the tourism market.

\section{References}

[1] Santos, M., Estradas Reais: introdução ao estudo dos caminhos do ouro e do diamante no Brasil, Estrada Real: Belo Horizonte, 2001.

[2] Leão, F., De volta à Estrada Real: uma viagem a pé pelas trilhas do século XVIII entre Rio de Janeiro e Ouro Preto, Rona: Belo Horizonte, 1999.

[3] Instituto Estrada Real, www.estradareal.org.br

[4] Interiorline, www.interiorline.com.br/blog/wp-content/uploads/2008/07/ estradareal.jpg

[5] Dias, M. V., Mato Dentro: viagem através dos tempos e contratempos da história de Conceição. Dossiê Agência de Investigação Histórica: Belo Horizonte, 1994.

[6] Silva, A., Pedreira, L. \& Abreu, P., Serra do Espinhaço Meridional: paisagens e ambientes, O Lutador: Belo Horizonte, 2005.

[7] Queiroz, S. F., La dimensión sociocultural de la sostenibilidad en el turismo de caminos, Tesis de doctorado: Bilbao, País Basco, España, 2007. 